\title{
Acute and chronic diabetes complications associated with self-reported oral health: a retrospective cohort study
}

\author{
Kamini Kaura Parbhakar ${ }^{1 *}$ D, Laura C. Rosella ${ }^{2,3}$, Sonica Singhal ${ }^{1,4}$ and Carlos R. Quiñonez ${ }^{1,2,3}$
}

\begin{abstract}
Background: Oral health is associated with diabetes, but the chances of experiencing acute or chronic diabetes complications as per this association is unknown in Canada's most populous province, Ontario. This study assesses the impact of self-reported oral health on the likelihood of experiencing acute and chronic complications among a cohort of previously diagnosed diabetics.

Methods: A retrospective cohort study was conducted of diabetics $(n=5183)$ who participated in the Canadian Community Health Survey 2003 and 2007-08. Self-reported oral health status was linked to health encounters in electronic medical records until March 31, 2016. Multinomial regression models determined the odds of the first acute or chronic complication after self-report of oral health status.

Results: Thirty-eight percent of diabetics reporting "poor to fair" oral health experienced a diabetes complication, in comparison to 34\% of those reporting "good to excellent" oral health. The odds of an acute or chronic complication among participants reporting "poor to fair" oral health status was 10\% (OR 1.10; 95\% Cl 0.81, 1.51) and 34\% (OR 1.34; $95 \% \mathrm{Cl} 1.11,1.61)$ greater respectively, than among participants experiencing no complications and reporting "good to excellent" oral health.

Conclusion: Self-reporting "poor to fair" oral health status is associated with a greater likelihood of chronic complications than acute complications. Further research regarding the underlying causal mechanisms linking oral health and diabetes complications is needed.
\end{abstract}

Keywords: Oral health, diabetes complications, periodontal disease, Population health, Acute, Chronic

\section{Background}

Diabetes is a major public health concern in Canada and worldwide. Characterized by hyperglycemia and the insufficient secretion or action of insulin, diabetes is a metabolic disorder that amplifies inflammatory immune responses resulting in diabetes complications $[1,2]$. The Canadian prevalence of diabetes currently sits at 3.65 million and is predicted to increase by over $30 \%$ within

\footnotetext{
*Correspondence: kamini.kaura@utoronto.ca

'Dental Public Health, Faculty of Dentistry, University of Toronto, Toronto, Ontario, Canada

Full list of author information is available at the end of the article
}

the next decade, and this is coupled with growing health care costs, morbidity, and premature mortality [3]. In Ontario, Canada's most populous province, the current prevalence of diabetes surpasses national estimates, arguably necessitating public health action [4].

Since the U.S. Surgeon General's Report on oral health in 2000, which placed a heavy emphasis on the relationship between oral health and systemic health, the link between diabetes and periodontal disease has received considerable attention [5]. Periodontal disease is a chronic inflammatory condition characterized by the destruction of oral tissues supporting teeth [6]. Although

(c) The Author(s). 2021, corrected publication 2021. Open Access This article is licensed under a Creative Commons Attribution 4.0 International License, which permits use, sharing, adaptation, distribution and reproduction in any medium or format, as long as you give appropriate credit to the original author(s) and the source, provide a link to the Creative Commons licence, and indicate if changes were made. The images or other third party material in this article are included in the article's Creative Commons licence, unless indicated otherwise in a credit line to the material. If material is not included in the article's Creative Commons licence and your intended use is not permitted by statutory regulation or exceeds the permitted use, you will need to obtain permission directly from the copyright holder. To view a copy of this licence, visit http://creativecommons.org/ licenses/by/4.0/. The Creative Commons Public Domain Dedication waiver (http://creativecommons.org/publicdomain/zero/1. 0/) applies to the data made available in this article, unless otherwise stated in a credit line to the data. 
periodontal disease is most commonly known as a complication of diabetes, the evidence indicates that the link between these two conditions may be bidirectional [7, 8]. Initiated by microbial dysbiosis, periodontal disease produces a low grade host immune response that can stimulate systemic inflammation $[9,10]$. Specifically, the shift in symbiotic microbial communities of the periodontal tissues accounts for an exaggerated immune defense mechanism leading to the destruction of periodontal tissues $[9,10]$. In turn, among diabetics, hyperglycemia accounts for an alteration in cell function, defective neutrophil apoptosis, oxidative stress, and the excessive production of inflammatory mediators that exacerbate insulin resistance resulting in health complications $[6,11,12]$. A unified inflammatory mechanism between periodontal disease and diabetics is thought to impact diabetes health outcomes and complications $[13,14]$.

Diabetes complications are classified as acute and chronic, and chronic complications are further classified as microvascular or macrovascular in nature [13]. Acute complications of diabetes include hyperglycemia and hypoglycemia, and chronic complications include cardiovascular diseases, kidney failure, retinopathy and neuropathy [13]. Diabetes complications with the highest prevalence and greatest cost to the Canadian health care system are predominantly chronic and include stroke, myocardial infarction, kidney failure, lower limb amputations and vision loss [3, 15]. Although the biological mechanism of acute and chronic complications has been long debated, there is some consensus on the differences between them and the possibility of a continuum from acute to chronic $[13,16]$. Acute complications of diabetes have been characterized by changes in metabolic control, specifically hyperglycemia [13, 17]. In contrast, chronic hyperglycemia is commonly assumed to be the central determinant in chronic diabetes complications. However, insulin resistance and macrovascular damage are found to play a large role $[13,17]$.

In the mechanism linking periodontal disease to diabetes, the role of insulin resistance and exaggerated immune inflammatory pathways have been considered the driving force in the "bidirectional" link $[1,2,18-20]$. To quantify the periodontal impact on diabetic health, studies have explored the effect that periodontal treatment has on blood sugar levels and lipid profile markers $[2,19,21,22]$. The current evidence for periodontal treatment among diabetics also suggests that periodontal disease may play the role of a risk factor, as periodontal treatment was found to reduce blood sugar levels as well as cholesterol levels and high-density lipids [21]. Periodontal care has also been associated with reductions in health complications, hospital admissions and overall medical and pharmaceutical costs among diabetics [2,
23-25]. However, there is no research using Canadian populations in relation to oral health and diabetes, and there is a paucity of population level evidence supporting the epidemiological association between oral and diabetes health generally [26]. This study thus aims to identify the odds of future acute and chronic complications among diabetics who have self-reported oral health status in Canada's most populous province, Ontario.

\section{Methods \\ Study design}

A retrospective cohort study was designed to explore the odds of acute and chronic diabetes complications among Ontario residents self-reporting oral health status. Study participants were selected from a combined pool of respondents interviewed from the 2003 and 2007-08 Canadian Community Health Survey (CCHS) [27]. Briefly, the CCHS is a national survey that utilizes a multi-stage, stratified, clustered-probability survey sampling design and is representative of $98 \%$ of the Canadian population [28]. The survey is administered by Statistics Canada and collects self-reported health information from Canadians over the age of 12, excluding those living on indigenous reserves, residing in institutions and full-time members of the Canadian armed forces [28]. Details regarding the CCHS methodology are documented elsewhere [28].

The study cohort was restricted to Ontario residents over the age of 40 with a validated diabetes diagnosis. As all residents of the province of Ontario are covered by a single payer insurance system, the Ontario Health Insurance Plan (OHIP), health system encounters among these participants can be followed. With de-identified health card numbers, health encounters in electronic medical records held by the Institute for Clinical Evaluative Sciences (ICES) were followed from the initial CCHS interview date, until March 31, 2016. A validated diabetes diagnosis was confirmed using the Ontario Diabetes Database (ODD), an ICES-derived disease registry containing physician diagnosed cases of diabetes in Ontario [29].

The final study sample was composed of individuals over the age of 40, who participated in the oral health component of the CCHS and had an ODD confirmed diagnosis of diabetes. Individuals were excluded if they could not be linked to electronic medical records, were OHIP-ineligible during the follow-up period, or if they did not report oral health status during survey administration. The final analytical sample consisted of 5183 participants, which represents a weighted sample of 1.31 million Ontario residents. Ethical approval for this study was obtained from the University of Toronto Research Ethics Board and was followed by ICES approval for data 
creation and access at Sunnybrook Hospital in Toronto, Ontario (protocol reference no. 34553).

\section{Oral health status}

CCHS cycles 2003 and 2007-08 were selected for the availability of oral health data for the province of Ontario [28]. Self-reported oral health status was assessed through the question "would you say the health of your teeth and mouth is: excellent, very good, good, fair or poor?". According to the distribution of selfreported oral health status among study participants and to determine the differences among positively and negatively inclined oral health responses, the exposure variable was re-categorized into two values representing "good to excellent" and "poor to fair" oral health categories. Further description of oral health content from the CCHS is described elsewhere [28].

\section{Diabetes complications}

The primary outcome of this study was the first diabetes complication experienced by participants after the CCHS interview date. Complications were extracted from hospitalization and emergency department records. International Classification of Disease (ICD-9) codes, were used to extract diabetes-specific complications from these data [30]. Acute complications included nonspecific hypoglycemia and hyperglycemia; chronic complications included myocardial infarction, stroke, skin infections, amputation, dialysis, and retinopathy. Following the CCHS interview, participants were classified in three categories comprising of those who did not experience any complication, those who experienced an acute complication and those who experienced a chronic complication.

\section{Covariates}

CCHS participants' demographic characteristics, health behaviours and medical histories, were included in the study as covariates, according to their association with oral health and diabetes outcomes. Covariates included the following: age, sex, income, education, rural/urban index, race, physical activity, smoking status, alcohol consumption, dental visits, basal metabolic index (BMI), prior co-morbidity, duration of diabetes prior to interview date, stress, community sense of belonging, health care visits prior to the complication and self-reported overall health.

Age, BMI and duration of diabetes were continuous measures while all other covariates were categorical. The duration of diabetes prior to interview date was used to consider the impact of a dated or early diabetes diagnosis. The Rurality Index of Ontario (RIO) was used to classify individuals residing in rural or urban areas. Participants with RIO scores $<39$ were categorized as urban residents and scores $\geq 40$ were categorized as rural residents [31]. Co-morbidity at the interview date was assessed from CCHS questions regarding chronic diseases and participants were classified into two categories comprising of participants without any co-morbidity and participants with any of the following conditions: arthritis, chronic obstructive pulmonary disease (COPD), heart disease and stroke. Health care visits was assessed by extracting OHIP codes for visits to a general practitioner or specialist. Visits were classified into three categories, comprising of participants who visited their general practitioner, specialist or both general and specialist practitioners for diabetes management.

\section{Statistical analysis}

Starting with baseline characteristics, all variables were assessed for their association with self-reported oral health. T-tests were used to express the means and standard deviations of continuous variables and Chisquared tests were used to express the cross tabulated frequencies of categorical variables. Bivariate analysis was conducted by the multi-categorical outcome. Furthermore, variables with a $p$-value $\leq 0.25$ following the baseline and bivariate analysis were included and the most parsimonious model was built [32]. Variables that did not reach a $\mathrm{p}$-value of $\leq 0.25$ but were associated with the exposure or outcome in the literature were also included in the model. Multinomial logistic regression models were used to determine the odds of experiencing an acute or chronic outcome following the interview date among participants reporting "poor to fair" oral health. Multinomial odds ratios with confidence intervals were estimated for diabetes complications associated with oral health, where individuals reporting "good to excellent" oral health status, whom did not experience any diabetes complications following the interview date, represented the reference group. Oral health was the explanatory variable and covariates were included in the model if they were clinically significant or were associated with diabetes outcomes in existing literature.

Bootstrapping sample weights provided by Statistics Canada were applied to the analysis to adjust for the complex nature of the CCHS survey design. This generated inferable estimates for the Ontario population. All statistical analyses were performed using SAS version 9.4 and data was accessed at Sunnybrook Hospital ICES Central in Toronto, Canada. PROC SURVEY MEANS, PROC SURVEYFREQ and PROC SURVEYLOGISTIC were used in the analysis [33].

\section{Results}

A total of 5183 diabetics over the age of 40 were followed through electronic medical records at ICES. As shown in Table 1, 38\% of those reporting "poor to fair" 
Table 1 Type of diabetes complications experienced by participants self-reporting their oral health status $(n=5183 ; N=1,308,911)$

\begin{tabular}{|c|c|c|c|c|}
\hline \multirow{2}{*}{$\begin{array}{l}\text { Oral Health } \\
\text { Status }\end{array}$} & \multicolumn{3}{|c|}{ Complication Type } & \multirow[t]{2}{*}{ Total } \\
\hline & No complication & Acute complication & Chronic complication & \\
\hline Good to Excellent & $2693(66 \%)$ & 199 (5\%) & $1198(29 \%)$ & 4090 \\
\hline Poor to Fair & $674(62 \%)$ & $55(5 \%)$ & 364 (33\%) & 1093 \\
\hline Total & 3367 & 254 & 1562 & 5183 \\
\hline
\end{tabular}

oral health experienced a diabetes complication. The prevalence of chronic complications in this subgroup was $33 \%$. In contrast, $34 \%$ of those reporting "good to excellent" oral health experienced a complication. The prevalence of chronic complications in this subgroup was approximately 29\%. Both groups experienced a similar frequency of acute complications at approximately $5 \%$.

Baseline characteristics of participants according to the diabetes outcome type are shown in Table 2. Participants who did not experience a complication were a mean age of approximately 62 years, while those who experienced an acute or chronic complication were a mean age of approximately 65 years. A majority of those who did not experience a complication were also male and self-reported higher income. The study sample was predominantly composed of individuals self-identifying as white, living in urban areas and having a post-secondary education. A greater majority of those who experienced an acute or chronic complication reported having other chronic diseases as well as a higher BMI and a longer duration of diabetes prior to the interview date. They were also current smokers, consumed alcohol regularly, lived predominantly inactive lifestyles and had not seen a dentist in the past 12 months.

The odds ratios shown in Table 3 depict the difference in the likelihood of an acute or chronic diabetes complication among study participants. In the fully adjusted multinomial regression, the odds of an acute complication versus no complication among participants reporting "poor to fair" versus "good to excellent" oral health was $10 \%$ greater $[\mathrm{OR}=1.10,95 \% \mathrm{CI} 0.81,1.51]$. The odds of those experiencing a chronic complication in the final model, versus no complication among participants reporting "poor to fair" versus "good to excellent" oral health was $34 \%$ greater [OR $=1.34,95 \% \mathrm{CI} 1.11,1.61]$.

Among covariates included in the multinomial model, age and income differences among participants were not significantly associated with the likelihood of acute and chronic complications. As sex was not found to be associated with the study outcome in the bivariate analysis, it was included in the fully adjusted model as an interaction term. However, with every unit increase in age among males and females, there was no effect on the likelihood of acute or chronic complications versus no complications. Trends are observed among education levels, self-reported general health, smoking and dental visits. For education levels, in comparison to those with a post-secondary education, those reporting having a secondary school diploma or less, had a higher likelihood of acute and chronic complications. Similarly, the further away from "good to excellent" a study participant self-reported their general health, the greater their odds for complications. Fewer dental visits and current smoking showed similar trends in comparison to those who visited the dentist more than twice in the past year and those who never smoked, respectively. A trend among those consuming alcohol regularly and occasionally was associated with greater odds of acute complications only.

Individuals identifying as an ethnic minority had higher odds for acute complications and lower odds for chronic complications. Interestingly, those who were living in rural areas, in comparison to those in urban areas, had a higher likelihood for chronic than acute complications. For every unit increase in BMI, there was only a slight but insignificant increase in the odds for chronic complications in comparison to acute complications. Those who reported having comorbidities prior to the interview date showed a similar trend leaning towards greater odds of chronic complications. However, those who had diabetes for a longer duration prior to the interview date were observed to have higher odds for acute complications than chronic complications. Those who were found to have had contact with only a general physician prior to any complication were at a lower likelihood of experiencing acute or chronic complications. In contrast, those who only had contact with a specialist were at a higher risk. Those who had contact with both a general physician and specialist were considered the reference group.

\section{Discussion}

This study's findings indicate that "poor to fair" selfreported oral health is associated with a greater likelihood for chronic complications than acute complications, after adjusting for an extensive range of covariates. This is in line with studies that have found that diabetics with periodontal disease or those who do not receive periodontal treatment, incur higher medical costs and a greater number of hospitalizations, and supports the association between periodontal disease and chronic diabetes complications [24, 25, 34-37]. This 
Table 2 Baseline weighted characteristics of study participants according to type of complication outcome ( $n=$ 5183; $N=1,308,911$ )

\begin{tabular}{|c|c|c|c|}
\hline \multirow[t]{2}{*}{ Baseline Characteristics } & \multicolumn{3}{|c|}{ Diabetes Complications } \\
\hline & $\begin{array}{l}\text { No } \\
\text { Complication } \\
(\boldsymbol{n}=3367)\end{array}$ & $\begin{array}{l}\text { Acute } \\
\text { Complication } \\
(\boldsymbol{n}=254)\end{array}$ & $\begin{array}{l}\text { Chronic } \\
\text { Complication } \\
(\boldsymbol{n}=1562)\end{array}$ \\
\hline Age (Mean, \pm SD) & $61.6 \pm 0.4$ & $64.8 \pm 1.4$ & $65.6 \pm 0.7$ \\
\hline Sex (\% Male) & 51.8 & 42.2 & 44.1 \\
\hline Race (\%White) & 72.7 & 80.9 & 82.4 \\
\hline \multicolumn{4}{|l|}{ Income (\%) } \\
\hline Quintile 1 & 14.7 & 19.0 & 18.1 \\
\hline Quintile 2 & 13.2 & 9.8 & 15.1 \\
\hline Quintile 3 & 20.4 & 16.2 & 17.8 \\
\hline Quintile 4 & 19.2 & 17.7 & 22.0 \\
\hline Quintile 5 & 17.9 & 21.1 & 14.7 \\
\hline \multicolumn{4}{|l|}{ Education (\%) } \\
\hline$<$ Diploma & 21.0 & 33.8 & 31.9 \\
\hline Diploma & 12.3 & 13.1 & 16.3 \\
\hline Post-Secondary & 61.6 & 48.4 & 49.2 \\
\hline \multicolumn{4}{|l|}{ RIO (\%) } \\
\hline Urban & 92.3 & 91.0 & 87.7 \\
\hline Rural & 7.7 & 9.0 & 12.4 \\
\hline Chronic disease (\%) & 49.6 & 65.8 & 64.4 \\
\hline BMI (Mean, SD) & $27.8 \pm 0.2$ & $28.4 \pm 0.8$ & $28.6 \pm 0.3$ \\
\hline $\begin{array}{l}\text { DM duration (years) } \\
\text { (Mean, SD) }\end{array}$ & $6.4 \pm 0.2$ & $10.4 \pm 0.5$ & $7.4 \pm 0.2$ \\
\hline Stress (\%) & 43.2 & 38.7 & 39.9 \\
\hline \multicolumn{4}{|l|}{ Health status (\%) } \\
\hline Excellent & 6.5 & 3.9 & 4.7 \\
\hline Very good & 21.9 & 8.1 & 16.1 \\
\hline Good & 38.2 & 33.1 & 31.0 \\
\hline Fair & 23.4 & 32.6 & 30.8 \\
\hline Poor & 10.0 & 22.3 & 17.9 \\
\hline $\begin{array}{l}\text { Community belonging } \\
(\%)\end{array}$ & 66.7 & 65.5 & 64.4 \\
\hline \multicolumn{4}{|l|}{ Smoking (\%) } \\
\hline Current & 13.5 & 21.3 & 17.6 \\
\hline Former & 46.8 & 46.8 & 48.2 \\
\hline Never smoked & 39.7 & 33.3 & 34.2 \\
\hline \multicolumn{4}{|l|}{ Alcohol use (\%) } \\
\hline Regular & 46.2 & 31.9 & 41.2 \\
\hline Occasionally & 18.3 & 23.8 & 21.7 \\
\hline Former & 30.8 & 39.8 & 31.4 \\
\hline Never drank & 4.7 & 4.5 & 5.9 \\
\hline \multicolumn{4}{|l|}{ Activity index (\%) } \\
\hline Active & 17.9 & 14.4 & 17.7 \\
\hline Mod. active & 21.9 & 13.7 & 19.1 \\
\hline
\end{tabular}

Table 2 Baseline weighted characteristics of study participants according to type of complication outcome ( $n=$ 5183; $N=1,308,911$ ) (Continued)

\begin{tabular}{llll}
\hline Baseline Characteristics & \multicolumn{3}{l}{ Diabetes Complications } \\
\cline { 2 - 4 } & $\begin{array}{l}\text { No } \\
\text { Complication } \\
(\boldsymbol{n}=3367)\end{array}$ & $\begin{array}{l}\text { Acute } \\
\text { Complication } \\
(\boldsymbol{n}=254)\end{array}$ & $\begin{array}{l}\text { Chronic } \\
\text { Complication } \\
(\boldsymbol{n}=1562)\end{array}$ \\
\hline $\begin{array}{l}\text { Inactive } \\
\text { Dental visits (\%) }\end{array}$ & 60.2 & 71.8 & 63.1 \\
0/year & 37.6 & 46.2 & 45.8 \\
1-2 Visits/year & 45.5 & 42.2 & 40.1 \\
$>$ 2 Visits/year & 16.9 & 11.7 & 14.1 \\
Health care visits (\%) & & & \\
General Physician & 11.1 & 2.3 & 3.1 \\
Specialist & 8.7 & 15.6 & 12.2 \\
GP + SP & 80.2 & 82.1 & 84.7 \\
\hline
\end{tabular}

*Note: percentages may not add up to $100 \%$ because of missing categories or rounding

study provides insights about the likelihood for complications among diabetics in Ontario, Canada.

Over the last century, many hypotheses have been developed to explain the oral-systemic link, based on the microbial dysbiosis of periodontal disease [38]. Oral pathogens are thought to impact systemic health by either direct invasion or the indirect stimulation of immune-inflammatory responses $[38,39]$. The inconsistency of evidence on direct invasion lead scientists to find more support for the hypothesis of indirect invasion, which may explain the bidirectional impact of periodontal disease [36, 38, 39]. Although our study does not seek to support one hypothesis over the other, nor does it claim causation, the greater likelihood of chronic complications in this study may be explained by the proposition that indirectly exaggerated immune inflammatory responses link periodontal disease to diabetes [40-42].

However, in order to interpret the greater odds of chronic complications than acute complications observed among diabetics reporting "poor to fair" oral health status, it is important to understand the difference between the mechanism of acute and chronic diabetes complications. The literature suggests that the basis of acute diabetes complications is metabolic imbalances and hyperglycemia [13, 17]. Chronic complications are further characterized by insulin resistance that can lead to micro- and macrovascular damage $[13,16,17$, 43]. Although clinical trials have explored the impact of periodontal treatment on the reduction of blood sugar levels, only a few have explored the reduction of lipid markers such as cholesterol, triglycerides and highdensity lipids, which are important contributors of insulin resistance and are associated with greater chronic complications [44-48]. Some studies also support the 
Table 3 Odds ratios and 95\% confidence intervals from a fully adjusted multinomial logistic regression for the relation between self-reported oral health and diabetes complications

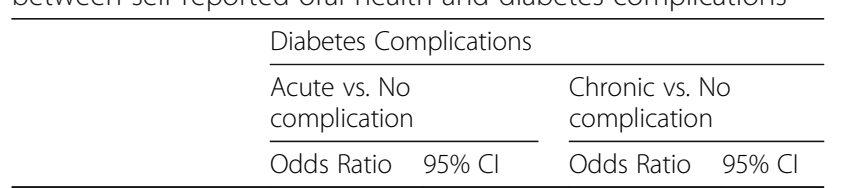

\section{Self-reported oral health}

Good to excellent 1.00

Poor to fair $\quad 1.10$

Age

1.00

Age*Sex

Male

Female

1.00

Race

White

1.00

Ethnic minority

1.12

Income

$\begin{array}{ll}\text { Quintile 1 } & 0.34 \\ \text { Quintile 2 } & 0.30 \\ \text { Quintile 3 } & 0.35 \\ \text { Quintile 4 } & 0.46 \\ \text { Quintile 5 } & 1.00\end{array}$

Education

$\begin{array}{ll}\text { < Diploma } & 2.39 \\ \text { Diploma } & 1.53 \\ \text { Post-secondary } & 1.00\end{array}$

Rurality index of Ontario

$\begin{array}{ll}\text { Urban } & 1.00 \\ \text { Rural } & 1.18 \\ \text { Chronic disease } & 1.05 \\ \text { BMI } & 1.00 \\ \text { DM duration } & 1.22 \\ \text { Self-reported general health }\end{array}$

Self-reported general health

$\begin{array}{lllll}\text { Excellent } & 1.00 & - & 1.00 & - \\ \text { Very good } & 0.44 & 0.04,5.19 & 0.83 & 0.57,1.20 \\ \text { Good } & 1.06 & 0.09,12.64 & 0.87 & 0.60,1.26 \\ \text { Fair } & 1.32 & 0.11,15.78 & 1.11 & 0.78,1.59 \\ \text { Poor } & 1.76 & 0.14,22.56 & 1.53 & 1.01,2.33 \\ \text { Smoking } & & & & \\ \text { Current } & 1.77 & 1.08,2.88 & 1.17 & 0.90,1.51 \\ \text { Former } & 1.06 & 0.77,1.46 & 0.90 & 0.76,1.07 \\ \text { Never smoked } & 1.00 & - & 1.00 & - \\ \text { Dental Visits } & & & & \\ \text { O/year } & 1.68 & 1.19,2.39 & 1.27 & 1.04,1.55 \\ \text { 1-2 Visits/year } & 1.68 & 1.62,2.44 & 1.05 & 0.84,1.31 \\ >\text { 2 Visits/year } & 1.00 & - & 1.00 & -\end{array}$

Table 3 Odds ratios and 95\% confidence intervals from a fully adjusted multinomial logistic regression for the relation between self-reported oral health and diabetes complications (Continued)

\begin{tabular}{|c|c|c|c|c|}
\hline & \multicolumn{4}{|c|}{ Diabetes Complications } \\
\hline & \multicolumn{2}{|c|}{$\begin{array}{l}\text { Acute vs. No } \\
\text { complication }\end{array}$} & \multicolumn{2}{|c|}{$\begin{array}{l}\text { Chronic vs. No } \\
\text { complication }\end{array}$} \\
\hline & Odds Ratio & $95 \% \mathrm{Cl}$ & Odds Ratio & $95 \% \mathrm{Cl}$ \\
\hline \multicolumn{5}{|l|}{ Alcohol use } \\
\hline Regular & 1.05 & $0.40,2.75$ & 0.63 & $0.40,1.00$ \\
\hline Occasionally & 1.82 & $0.69,4.75$ & 0.86 & $0.53,1.41$ \\
\hline Former & 1.43 & $0.57,3.59$ & 0.64 & $0.41,1.01$ \\
\hline Never drank & 1.00 & - & 1.00 & - \\
\hline \multicolumn{5}{|l|}{ Health care visit } \\
\hline General Physician & 0.73 & $0.18,2.94$ & 0.38 & $0.20,0.70$ \\
\hline Specialist & 1.52 & $0.67,3.45$ & 1.36 & $0.99,1.87$ \\
\hline $\mathrm{GP}+\mathrm{SP}$ & 1.00 & - & 1.00 & - \\
\hline
\end{tabular}

use of BMI as a predictive measure for insulin resistance, however, BMI was not found to have a significant effect on either acute or chronic complications in this current study [49]. As insulin resistance may be the connecting factor for periodontal disease and chronic diabetes complications, further research into this component of the putative bidirectional link may provide insight into preventive measures. At the public health level, for instance, where health outcomes, health expenditures and improved quality of life is of concern, this may provide support for concurrent demands for improvements in access to dental care in Canada and better management of diabetes, reductions in inefficient healthcare costs, such as physician and emergency department use for oral health-related complaints [50, 51], and improvements to the quality of life of diabetics [52].

This study presents with several strengths. Primarily, it has been conducted at the population level, allowing for population-based inferences for diabetics over the age of 40. Second is the use of a validated diabetes diagnosis, which contrasts most of the current literature [24, 25]. In comparison with observational studies, our retrospective selection of participants and longitudinal follow-up allows for arguments beyond a simple association between self-reported oral health and diabetes complications. The use of self-reported oral health also presents as a strength in this study. As self-reported oral health is multi-faceted in nature, representing the social, psychosocial, economic and cultural components of oral health, it presents as a convenient measure for exploring the diabetes health experience [53-55]. Notably, studies have found that self-reported oral health status is consistent with the clinical need for oral treatment [56]. Among diabetics, this measure can thus arguably be 
used to assess the odds of diabetes complications and provide a means to improve health literacy and expand the referral network for diabetics in need of dental care [57].

Despite these strengths, there are also important limitations to consider. Although self-reported oral health status can be an effective measure to predict oral health needs, it may not be a competent measure for clinical periodontitis [54]. The evidence shows that self-reported oral health can be highly specific but not sensitive [56]. Thus, the current study's participants may be able to report that they do not have periodontal disease with greater accuracy that those with the condition [56]. However, the evidence also suggests that diabetics may be more aware of their periodontal disease status [58, 59]. Although clinical measures of periodontal disease and diabetes control would provide greater power to our study, such measures have not been linked to electronic medical records in Canada. Using the ODD also presents with the limitation that this database does not differentiate between type 1 or 2 diabetics [29]. As the periodontal disease-diabetes link is based on the pathological mechanism of adult onset diabetes, this limitation may overestimate results; however, as more than $95 \%$ of the ODD is made up of type 2 diabetics and the sample was restricted to participants over the age of 40 , the impact of type 1 diabetics is minimal and does not arguably impact the study results.

\section{Conclusion}

Overall, this study's findings support the need for understanding the relationship between oral health status and diabetes complications. Within its limits, "poor to fair" oral health was found to be associated with a greater likelihood of chronic complications than acute complications, providing an important insight for diabetes health in Ontario, Canada.

\section{Abbreviations}

BMI: Basal metabolic index; CCHS: Canadian Community Health Survey; COPD: Chronic obstructive pulmonary disease; ICD: International Classification of Disease; ICES: Institute for Clinical Evaluative Sciences; ODD: Ontario Diabetes Database; OHIP: Ontario Health Insurance Plan; RIO: Rurality Index of Ontario

\section{Acknowledgements}

NA

\section{Authors' contributions}

KKP contributed to study conceptualization, data acquisition, methodology, formal analysis, writing original draft and critical revision of manuscript. LCR contributed to study conceptualization, methodology, and critical revision of manuscript. SS contributed to study conceptualization and critical revision of the manuscript. CRQ contributed to study conceptualization, supervision and critical revision of manuscript. All authors read and approved the final manuscript.

\section{Funding}

This study was supported a grant received from the Canadian Foundation of Dental Hygiene Research and Education and the David Locker Graduate Scholarship in Dental Public Health from the University of Toronto. Further support for this study was generously provided by Green Shield Canada (GSC) and the Institute for Clinical Evaluative Sciences (ICES), which is funded by an annual grant from the Ontario Ministry of Health and Long-Term Care (MOHLTC).

The funders were not involved with the design or conduct of the study; collection, management, analysis or interpretation of the data; preparation, review or approval of the manuscript; or decision to submit the manuscript for publication.

\section{Availability of data and materials}

The linked data used for this study is held securely in coded form at the Institute for Clinical Evaluative Sciences (ICES). ICES is a not-for-profit research institute whose mandate is to enable health system evaluation and research. ICES has custody and control of a array of Ontario health information ("ICES data"), collected and used by ICES in accordance with applicable law, research ethics approvals and contractual commitments. As a prescribed entity under s. 18(1) of O.Reg 329/04 of Ontario's Personal Health Information Protection Act (PHIPA), ICES is authorized to disclose ICES data for research that is described in a research plan that meets the requirements of s. 44(2) of the Act and approved by a research ethics board, or in the case of research approved outside of Ontario, for research that meets the requirements of $\mathrm{s}$. 44(10). All administrative data received and held at ICES are used only for the approved research. Only de-identified variables, specific to answer the study questions, are used for the above purpose. Variables are pre-defined in a standardized Dataset Creation Plan (DCP). ICES Data are held on secure ICES servers, located in a restricted area within ICES' locked and 24/7/365 videomonitored facility. Authorized researchers access ICES data remotely through a secure, encrypted VMware Virtual Desktop, requiring two-factor authentication. ICES data cannot be copied or transferred from the VMware Virtual Desktop, except for results of analysis of ICES data, which may be removed subject to ICES' approval. Furthermore, no data will be released which could potentially be used in the reidentification of individuals. For example, small cells (consisting of between one and five people) must be suppressed. These ICES methodologies are in place to minimize the risk of identity and attribute disclosure. To request data, please contact Melissa Chiarelli; Research Program Coordinator, Primary Care \& Population Health; melissa.chiarelli@ices. on.ca; 416-480-4055 × 6047 .

\section{Ethics approval and consent to participate}

Ethical approval for this study was obtained from the University of Toronto Health Sciences Research Ethics Board followed by subsequent ICES approval for data creation and access (protocol reference \#34553). Data from all databases used for this study were de identified and no extraction of personally identifiable information occurred. There was no recruitment of any participants, no access to patient identifiers, and no contact with individuals. The need for consent was thus waived by the University of Toronto and ICES. All administrative data received and held at ICES are used only for the approved research. Only de-identified variables specific to the study were used. ICES data cannot be copied or transferred out of ICES, except for the results of analysis, which may be removed subject to ICES approval.

\section{Consent for publication}

Not applicable.

\section{Competing interests}

The authors have declared that no competing interests exist. Carlos Quiñonez receives consulting income for dental care related issues from Green Shield Canada.

\section{Author details}

'Dental Public Health, Faculty of Dentistry, University of Toronto, Toronto, Ontario, Canada. ${ }^{2}$ Division of Epidemiology, Dalla Lana School of Public Health, University of Toronto, Toronto, Ontario, Canada. ${ }^{3}$ Institute for Clinical Evaluative Sciences, Toronto, Ontario, Canada. ${ }^{4}$ Public Health Ontario

Toronto, Ontario, Canada. 
Received: 19 December 2019 Accepted: 27 February 2020 Published online: 07 March 2020

\section{References}

1. Kassebaum NJ, Smith AGC, Bernabé E, Fleming TD, Reynolds AE, Vos T, et al. Global, Regional, and National Prevalence. Incidence, and Disability-Adjusted Life Years for Oral Conditions for 195 Countries, 1990-2015: A Systematic Analysis for the Global Burden of Diseases, Injuries, and Risk Factors. J Dent Res [Internet]. 2017 Apr;96(4):380-7. Available from: http://journals.sagepub. com/doi/10.1177/00220345176935661 [cited 201814 Aug].

2. Simpson TC, Weldon JC, Worthington HV, Needleman I, Wild SH, Moles DR, Stevenson B, Furness S, Iheozor-Ejiofor Z. Treatment of periodontal disease for glycaemic control in people with diabetes mellitus. Cochrane Database Syst Rev. 2015;(11):CD004714. https://doi.org/10.1002/14651858.CD004714. pub3.

3. Canadian Diabetes Association. Charter BackgrounderDiabetes in Canada [Internet]. 2018 [cited 2018 Sep 19]. Available from: https://www.canada.ca/ content/dam/phac-aspc/migration/phac-aspc/cd-.

4. Charter Backgrounder : Diabetes in Ontario [Internet]. 2018 [cited 2018 Sep 19]. Available from: https://www.canada.ca/content/dam/phac-aspc/ migration/phac-aspc/cd-.

5. Oral Health in America: A Report of the Surgeon General [Internet]. 2000. Available from: https://profiles.nlm.nih.gov/ps/access/NNBBJT.pdf.

6. Hajishengallis $\mathrm{G}$. The inflammophilic character of the periodontitisassociated microbiota. Mol Oral Microbiol 2014;.

7. Chee B, Park B, Bartold PM. Periodontitis and type II diabetes: a two-way relationship. International Journal of Evidence-Based Healthcare 2013;

8. Taylor GW, Borgnakke WS. Periodontal disease: associations with diabetes, glycemic control and complications. Oral Dis. 2008;14(3):191-203.

9. Hasturk H, Kantarci A, Van Dyke TE. Oral Inflammatory Diseases and Systemic Inflammation: Role of the Macrophage. Front Immunol. 2012;16(3): 118 Available from: http://journal.frontiersin.org/article/10.3389/fimmu.2012. 00118/abstract[cited 201815 Aug].

10. Tsakos G, Quiñonez C. A sober look at the links between oral and general health. Journal of Epidemiology and Community Health. 2013;

11. Monnier L, Mas E, Ginet C, Michel F, Villon L, Cristol J-P, et al. Activation of Oxidative Stress by Acute Glucose Fluctuations Compared With Sustained Chronic Hyperglycemia in Patients With Type 2 Diabetes. JAMA. 2006; 295(14):1681 Available from: http://jama.jamanetwork.com/article.aspx?doi= 10.1001/jama.295.14.168112 [cited 20184 Oct].

12. MOUTSOPOULOS NM, PN MADIANOS. Low-Grade Inflammation in Chronic Infectious Diseases: Paradigm of Periodontal Infections. Ann N Y Acad Sci. 2006;1088(1):251-64 Available from: http://doi.wiley.com/10.1196/annals. 1366.0321 [cited 201822 Aug].

13. Brownlee M. The pathobiology of diabetic complications: a unifying mechanism. In: Diabetes. 2005. p. 1615-25.

14. Sanz M, Ceriello A, Buysschaert M, Chapple I, Demmer RT, Graziani F, et al. Scientific evidence on the links between periodontal diseases and diabetes: Consensus report and guidelines of the joint workshop on periodontal diseases and diabetes by the International Diabetes Federation and the European Federation of Periodontology. J Clin Periodontol. 2018 1;45(2): 138-49. Available from: http://doi.wiley.com/10.1111/jcpe.12808 [cited 2018 4 Oct].

15. Public Health Agency of Canada. Diabetes in Canada: Facts and figures from a public health perspective [Internet]. 2011. Available from: http://www. phac-aspc.gc.ca/cd-mc/diabetes-diabete/index-eng.php.

16. Chawla A, Chawla R, Jaggi S. Microvasular and macrovascular complications in diabetes mellitus: Distinct or continuum? Indian J Endocr Metab. Medknow Publications. 2016;20(4):546-53.

17. Cagliero E. Diabetes and Long-Term Complications. In: Endocrinology: Adult and Pediatric. Elsevier. 2016:898-906 e3.

18. Casanova L, Hughes FJ, Preshaw PM. Diabetes and periodontal disease: a two-way relationship. Br Dent J 2014;

19. Demmer RT, Jacobs DR, Singh R, Zuk A, Rosenbaum M, Papapanou PN, et al. Periodontal Bacteria and Prediabetes Prevalence in ORIGINS. J Dent Res [Internet]. 2015 16;94(9_suppl):201S-211S. Available from: http://journals. sagepub.com/doi/10.1177/0022034515590369 [cited 201920 Nov].

20. Kebede TG, Pink C, Rathmann W, Kowall B, Völzke H, Petersmann A, et al.. Does periodontitis affect diabetes incidence and haemoglobin A1c change? An 11-year follow-up study. Diabetes Metab [Internet]. 2018 Jun ;44(3):243-
249. Available from: https://linkinghub.elsevier.com/retrieve/pii/ S1262363617305761[cited 201814 Aug].

21. Garde S, Akhter R, Nguyen MA, Chow CK, Eberhard J. Periodontal Therapy for Improving Lipid Profiles in Patients with Type 2 Diabetes Mellitus: A Systematic Review and Meta-Analysis. Int J Mol Sci. 2019 5;20(15):3826. Available from: https://www.mdpi.com/1422-0067/20/15/3826 [cited 2019 $21 \mathrm{Nov}]$.

22. Kramer CK, Zinman B, Retnakaran R. Short-term intensive insulin therapy in type 2 diabetes mellitus: a systematic review and meta-analysis. Lancet Diabetes Endocrinol. 2013;1(1):28-34.

23. Albert DA, Sadowsky D, Papapanou P, Conicella ML, Ward A. An examination of periodontal treatment and per member per month (PMPM) medical costs in an insured population. BMC Health Serv Res [Internet]. 2006 Aug 16 [cited 2018 Aug 14];6:103. Available from: http://www.ncbi. nlm.nih.gov/pubmed/16914052.

24. Nasseh K, Vujicic M, Glick M. The Relationship between Periodontal Interventions and Healthcare Costs and Utilization. Evidence from an Integrated Dental, Medical, and Pharmacy Commercial Claims Database. Health Econ [Internet]. 2017 1;26(4):519-527. Available from: http://doi.wiley. com/10.1002/hec.3316 [cited 201814 Aug].

25. Jeffcoat MK, Jeffcoat RL, Gladowski PA, Bramson JB, Blum JJ. Impact of Periodontal Therapy on General Health: Evidence from Insurance Data for Five Systemic Conditions. Am J Prev Med [Internet]. 2014 1; 47(2):166-174. Available from: https://www.sciencedirect.com/science/ article/pii/S0749379714001536?via\%3Dihub [cited 201814 Aug].

26. Sanz M, Ceriello A, Buysschaert M, Chapple I, Demmer RT, Graziani F, et al. Scientific evidence on the links between periodontal diseases and diabetes: Consensus report and guidelines of the joint workshop on periodontal diseases and diabetes by the International Diabetes Federation and the European Federation of Periodontology. J Clin Periodontol [Internet]. 2018; 45:138-49. Available from: https://doi [cited 2018 22].

27. Thomas S, Wannell B. Combining cycles of the Canadian community Health survey. Heal Reports. 2009;20(1):55-60.

28. Statistics Canada. Canadian Community Health Survey-Annual Component (CCHS) [Internet]. [cited 2018 Aug 15]. Available from: http://www23.statcan. gc.ca/imdb/p2SV.pl?Function=getSurvey\&SDDS=3226.

29. Hux JE, Ivis F, Flintoft V, Bica A. Diabetes in Ontario Determination of prevalence and incidence using a validated administrative data algorithm [Internet]. [cited 2018 Aug 15]. Available from: http://care.diabetesjournals. org/content/25/3/512.full-text.pdf.

30. Booth G, Polsky J, Gozdyra G, Caucg-Dudek K, Kiran T, Shah B, et al. Regional Measures of Diabetes Burden in Ontario [Internet]. 2012 [cited 2018 Aug 16]. Available from: https://www.ices.on.ca/Publications/Atlasesand-Reports/2012/Regional-Measures-of-Diabetes-Burden-in-Ontario.

31. Glazier R, Zagorski B, Rayner J. Comparison of Primary Care Models in Ontario by Demographics, Case Mix and Emergency Department Use, 2008/ 09 to 2009/10 [Internet]. 2012 [cited 2018 Aug 20]. Available from: www. ices.on.ca.

32. Hosmer DW, Lemeshow S, May S. Applied survival analysis : regression modeling of time-to-event data [Internet]. Wiley-Interscience; 2008 [cited 2018 Aug 30]. 392 p. Available from: https://books.google.ca/books/about/ Applied_Survival_Analysis.html?id=IvvOoplqzWsC\&printsec= frontcover\&source=kp_read_button\&redir_esc $=y \# v=$ onepage\& $q \& f=f a l s e$.

33. SAS Enterprise 9.4., SAS Institute Inc., Cary, NC, USA.

34. Borgnakke WS, YI€ ostalo PV, Taylor GW, Genco RJ. Effect of periodontal disease on diabetes: systematic review of epidemiologic observational evidence. J Periodontol [Internet]. 2013 Apr;84(4-s):S135-52. Available from: http://www.ncbi.nlm.nih.gov/pubmed/23631574.

35. Sharma P, Dietrich T, Ferro CJ, Cockwell P, Chapple ILC. Association between periodontitis and mortality in stages 3-5 chronic kidney disease: NHANES III and linked mortality study. J Clin Periodontol [Internet]. 2016 Feb 1 [cited 2018 Oct 9];43(2):104-113. Available from: http://doi.wiley.com/ 10.1111/jcpe.12502.

36. Chapple ILC, Genco R. Diabetes and periodontal diseases: consensus report of the Joint EFP/AAP Workshop on Periodontitis and Systemic Diseases. J Clin Periodontol [Internet]. 2013 Apr;40:S106-S112. Available from: http:// doi.wiley.com/10.1111/jcpe.12077 [cited 20188 Oct].

37. Tonetti MS, Van Dyke TE, Working group 1 of the joint EFP/AAP workshop. Periodontitis and atherosclerotic cardiovascular disease: consensus report of the Joint EFP/AAPWorkshop on Periodontitis and Systemic Diseases. J Periodontol [Internet]. 2013;84(4-s):S24-S29. 
Available from: http://www.ncbi.nlm.nih.gov/pubmed/23631582 [cited $201822 \mathrm{Oct}]$

38. Kumar PS. From focal sepsis to periodontal medicine: a century of exploring the role of the oral microbiome in systemic disease. J Physiol [Internet]. 2017 Jan 15;595(2):465-476. Available from: http://doi.wiley.com/10.1113/ JP272427 [cited 20188 Oct].

39. Spolarich AE, Panagakos FS. Prevention Across the Lifespan: A Review of Evidence-Based Interventions for Common Oral Conditions [Internet]. 2017. Available from: http://www.saskohc.ca/images/documents/PDF/Reports/ Prevention-Across-the-Lifespan-A-Review-of-Evidence-Based-Interventionsfor-Common-Oral-Conditions.pdf\#page=216 [cited 20188 Oct].

40. Singer M, Bulled N, Ostrach B, Mendenhall E. Syndemics and the biosocial conception of health. Lancet [Internet]. 20174 [cited 2018 Aug 28]; 389(10072):941-50. Available from: https://www.sciencedirect.com/science/ article/pii/S014067361730003X

41. Hein C, Small D. Combating diabetes, obesity, periodontal disease and interrelated inflammatory conditions with a syndemic approach. Gd Rounds Oral-Sys Med [Internet]. 2006 [cited 2018 23];2:36-47. Available from: www. thesystemiclink.com.

42. Graziani F, Gennai S, Solini A, Petrini M. A systematic review and metaanalysis of epidemiologic observational evidence on the effect of periodontitis on diabetes An update of the EFP-AAP review. J Clin Periodontol [Internet]. 2018 [cited 2018 Oct 8];45(2):167-87. Available from: http://www.ncbi.nlm.nih.gov/pubmed/29277926.

43. Khumaedi Al, Purnamasari D, Wijaya IP, Soeroso Y. The relationship of diabetes, periodontitis and cardiovascular disease. Vol. 13, Diabetes and Metabolic Syndrome: Clinical Research and Reviews. Elsevier Ltd; 2019. p. 1675-8.

44. Chen L, Luo G, Xuan D, Wei B, Liu F, Li J, et al. Effects of Non-Surgical Periodontal Treatment on Clinical Response, Serum Inflammatory Parameters, and Metabolic Control in Patients With Type 2 Diabetes: A Randomized Study. J Periodontol [lnternet]. 2012 Apr [cited 2019 Nov 29]; 83(4):435-43. Available from: http://doi.wiley.com/10.1902/jop.2011.110327.

45. D'Aiuto F, Gkranias N, Bhowruth D, Khan T, Orlandi M, Suvan J, et al. Systemic effects of periodontitis treatment in patients with type 2 diabetes: a 12 month, single-Centre, investigator-masked, randomised trial. Lancet Diabetes Endocrinol. 2018;6(12):954-65.

46. Kapellas K, Mejia G, Bartold P, Skilton M, Maple-Brown L, Slade G, et al. Periodontal therapy and glycaemic control among individuals with type 2 diabetes: reflections from the PerioCardio study. Int J Dent Hyg [Internet]. 2017 Nov [cited 2019 Nov 29];15(4):e42-51. Available from: http://doi.wiley. com/10.1111/idh. 12234 .

47. Masi S, Orlandi M, Parkar M, Bhowruth D, Kingston I, O'Rourke C, et al. Mitochondrial oxidative stress, endothelial function and metabolic control in patients with type II diabetes and periodontitis: a randomised controlled clinical trial. Int J Cardiol. 2018;271:263-8.

48. Sun W-L, Chen L-L, Zhang S-Z, Wu Y-M, Ren Y-Z, Qin G-M. Inflammatory Cytokines, Adiponectin, Insulin Resistance and Metabolic Control after Periodontal Intervention in Patients with Type 2 Diabetes and Chronic Periodontitis. Intern Med [Internet]. 2011 [cited 2019 Nov 29];50(15):1569-74. Available from: http://joi.jlc.jst.go.jp/JST.JSTAGE/internalmedicine/50. 5166? from=CrossRef.

49. Okura T, Nakamura R, Fujioka Y, Kawamoto-Kitao S, Ito Y, Matsumoto K, et al. Body mass index $\geq 23$ is a risk factor for insulin resistance and diabetes in Japanese people: a brief report. PLoS One 2018 1;13(7)e0201052.

50. Riddle MC, Herman WH. The cost of diabetes cared an elephant in the room. Vol. 41, Diabetes Care. American Diabetes Association Inc:; 2018. p. 929-32.

51. Friedman ME, Quiñonez C, Barrett EJ, Boutis K, Casas MJ. The Cost of Treating Caries-Related Complaints at a Children's Hospital Emergency Department . 2018;84-90.

52. Hussey PS, Wertheimer S, Mehrotra A. The association between health care quality and cost a systematic review. Vol. 158, Annals of Internal Medicine. American College of Physicians; 2013. p. 27-33.

53. Benyamini Y. Health and Illness Perceptions [Internet]. Oxford University Press; 2011 [cited 2018 Aug 23]. Available from: http://oxfordhandbooks. com/view/10.1093/oxfordhb/9780195342819.001.0001/oxfordhb9780195342819-e-013.

54. Wiener RC, Dwibedi N, Shen C, Findley PA, Sambamoorthi U. Clinical Oral Health Recommended Care and Oral Health Self-Report, NHANES, 2013-
2014. Adv Public Heal [Internet]. 2018 26:1-9. Available from: https://www. hindawi.com/journals/aph/2018/1893562/ [cited 201827 Aug].

55. Ma TE Lo, Lagaya-Estrada L, Jimeno C, Jasul G. Validation of self-reported oral health measures for predicting periodontitis among adult Filipinos with type 2 diabetes mellitus. Endocr Abstr [Internet]. 2015 [cited 2018 Aug 23]; 37(411). Available from: https://www.endocrine-abstracts.org/ea/0037/ ea0037EP411.htm

56. Farmer J, Ramraj C, Azarpazhooh A, Dempster L, Ravaghi V, Quiñonez C. Comparing self-reported and clinically diagnosed unmet dental treatment needs using a nationally representative survey. J Public Health Dent [Internet]. 2017 Sep 1 [cited 2018 Aug 27];77(4):295-301. Available from: http://doi.wiley.com/10.1111/jphd.12205.

57. Atchison KA, Rozier GR, Weintraub JA. Integration of Oral Health and Primary Care: Communication, Coordination, and Referral [Internet]. 2018 [cited 2018 Oct 8]. Available from: https://nam.edu/wp-content/uploads/ 2018/10/Integration-of-Oral-Health-and-Primary-Care.pdf.

58. Jansson H, Lindholm E, Lindh C, Groop L, Bratthall G. Type 2 diabetes and risk for periodontal disease: a role for dental health awareness. J Clin Periodontol [Internet]. 2006 Jun [cited 2018 Oct 8];33(6):408-14. Available from: http://www.ncbi.nlm.nih.gov/pubmed/16677329.

59. Lee PH, McGrath CPJ, Kong AYC, Lam TH. Self-report poor oral health and chronic diseases: the Hong Kong FAMILY project. Community Dent Oral Epidemiol 2013;

\section{Publisher's Note}

Springer Nature remains neutral with regard to jurisdictional claims in published maps and institutional affiliations.
Ready to submit your research? Choose BMC and benefit from:
- fast, convenient online submission
- thorough peer review by experienced researchers in your field
- rapid publication on acceptance
- support for research data, including large and complex data types
- gold Open Access which fosters wider collaboration and increased citations
- maximum visibility for your research: over $100 \mathrm{M}$ website views per year
At BMC, research is always in progress.
Learn more biomedcentral.com/submissions 